\title{
Miejsce i rola Listów w korpusie pism Pseudo-Dionizego
}

\author{
Bogna Kosmulska \\ (Uniwersytet Warszawski, Instytut Filozofii)
}

\section{Wprowadzenie}

Autor, współcześnie nazywany „Pseudo-Dionizym Areopagitą”, a dawniej „boskim Dionizym”, jest postacią tyleż tajemniczą, co i wpływową: trudzili się nad jego dziełami Syryjczycy, Grecy i łacinnicy, trudzą współcześni historycy, teolodzy i filozofowie religii. Czasem niesłusznie jest on uznawany za twórcę teologii apofatycznej, której był jednak głównym źródłem w myśli średniowiecznej i późniejszej ${ }^{1}$, słusznie zaś - za twórcę teoretycznego pojęcia hierarchii, które na kilka wieków zdominowało wyobraźnię chrześcijańską, w tym zwłaszcza łacińską².

1 Warto przywołać tu bardzo udane sformułowanie Rafała Tichego: „Na początku był Dionizy. Był na początku, choć w pewnym sensie był też na końcu. Cała wcześniejsza tradycja starożytnej mistyki, mająca takich Ojców jak Klemens Aleksandryjski, Orygenes czy Grzegorz z Nyssy, właśnie w mistyce Dionizego znajduje swe dopełnienie, ukoronowanie i najwspanialszy wyraz. Ale był też na początku, w nim bowiem ta pierwsza linia mistyki chrześcijańskiej zyskuje niejako swoją samoświadomość" (tenże, Ukryte Oblicze. O mistyce i mesjanizmie, Poznań 2013, s. 15). Zdania te można odnieść także do apofatyki, która, co więcej, ma także swoje równoległe linie rozwojowe. Być może owa samoświadomość negatywności poznania Boga, która jest siłą napędową mistyki, była właśnie skutkiem wyraźnego zetknięcia się dwóch z tych linii - chrześcijańskiej i pogańskiej - w myśli Pseudo-Dionizego. Samą natomiast trudność w ustaleniu historycznego pierwszeństwa w dziedzinie teologii apofatycznej, a także miejsce w niej Pseudo-Dionizego, interesująco prezentuje praca D. Carabine, The Unknown God. Negative Theology in the Platonic Tradition: Plato to Eriugena, Louvain 1995.

2 Ogólna idea hierarchiczności jako gradacji zstępowania i wstępowania, silnie zaznacza się w filozofii helleńskiej, zwłaszcza późnej, niemniej pojawia się ona - pytanie, na ile jako sku- 
Artykuł ma na celu przybliżenie stosunkowo najmniej komentowanej części korpusu pism Dionizjańskich, czyli Listów, z tym że nie będzie on analizą poszczególnych epistula, a raczej - jak to sygnalizuję w tytule - ich usytuowania i płynącego stąd wspólnego ich znaczenia. Potraktowanie ich zaś nie tyle jako dodatku do pozostałych dzieł tego autora, ile jako ważnej składowej całości Corpus Dionysiacum ${ }^{3}$, a wręcz - idąc za bp. Alexandrem Golitzinem - jako jej chrystocentrycznego zwieńczenia ${ }^{4}$, wydaje mi się rozwiązywać niektóre problemy interpretacyjne: zarówno te wewnątrztekstualne, jak i związane z zagadką tożsamości myśliciela (tzw. kwestią Dionizjańską), od której wypadnie mi zacząć.

tek wpływu pogańskiego - także w myśli chrześcijańskiej, rodząc w niej istotne napięcia (por. J. Meyendorff, Teologia bizantyjska. Historia i doktryna, przeł. J. Prokopiuk, Kraków 2007, s. 12 14). Niezależnie jednak od obecności owej idei, jej systematyczne chrześcijańskie rozwinięcie i utworzenie samego terminu hierarchia, mimo że pochodzi on od pogańskiego hierarchy, jest przypisywane Pseudo-Dionizemu (także łacińskie jego zapożyczenie wiąże się z recepcją tego autora przez Eriugenę) - zob. P. Rorem, Pseudo-Dionysius. A Commentary on the Texts and Introduction to Their Influence, Oxford 1993, s. 19 i nast.; T. Stępień, Hierarchia niebiańska jako wzór idealnej społeczności. Polityczny aspekt myśli Pseudo-Dionizego Areopagity, „Warszawskie Studia Teologiczne" 2014, t. 27, z. 1, s. 161-170.

3 Na Corpus Dionysiacum (= CD), wedle kolejności przyjętej we wszystkich greckich rękopisach, składają się: Hierarchie niebiańska $(=\mathrm{CH})$ i kościelna $(=\mathrm{EH})$, Imiona boskie $(=\mathrm{DN})$, Teologia mistyczna (= MTh) i Listy (= Ep.Ep.). W tych zachowanych utworach znajdują się również wzmianki, a nawet rodzaj streszczeń kilku innych dzieł, które - niezależnie o tego, czy rzeczywiście powstały (a jest to rzecz ze wszech miar wątpliwa - por. A. Louth, Denys the Areopagite, London 1989, s. 19-20) - mają jednak swoje miejsce w całościowym zamyśle teologiczno-filozoficznym Pseudo-Dionizego (por. H.U. von Balthasar, Chwała. Estetyka teologiczna, t. 2, cz. 1, przeł. E. Marszał i J. Zakrzewski, Kraków 2007, s. 152-161, zwł. s. 154).

4 Por. tenże, Mystagogy. A Monastic Reading of Dionysius Areopagita, Collegeville, Minnesota 2013 (nt. założeń tej pracy zob. tamże, s. xxxiii-xxxviii; wyewoluowała ona z wcześniejszej, również bardzo inspirującej monografii tego autora Et introibo ad altare Dei: Mystagogy of Dionysius Areopagita, $\Theta \varepsilon \sigma \sigma \alpha \lambda$ ovík 1 1994). Ta chrystocentryczna orientacja Pseudo-Dionizego była chyba wyraźna dla autorów bizantyńskich (a może raczej stanowiła założenie ich lektury), dla współczesnych badaczy, zwłaszcza dla znawców neoplatonizmu, nie jest jednak oczywista (por. np. W. Beierwaltes, Dionizy Areopagita - chrześcijański Proklos?, w: tegoż, Platonizm w chrześcijaństwie, przeł. P. Domański, Kęty 2003, zwłaszcza s. 68 i nn.). W kontekście nieoczywistej recepcji chrystocentrycznej także w samym Bizancjum por. też tezę Johna Meyendorffa o potrzebie „chrystologicznej korekty” dzieła Dionizjańskiego, jakiej miała dokonać późniejsza grecka tradycja, zwłaszcza palamicka. Zarówno współczesne spory wokół tej problematyki, jak i próbę historycznego się z nią zmierzenia podejmuje Agnieszka Świtkiewicz-Blandzi w pracy Pseudo-Dionizy a Grzegorz Palamas. Bizantyjska synteza wschodniej patrystyki, Warszawa 2018. Autorka wprawdzie odwołuje się w swoich rozważaniach do dzieł Aleksandra Golitzina, a nawet dochodzi do zbliżonych wniosków co prawosławny badacz - o pewnej sztuczności zagadnienia tak postawionego przez Meyendorffa - niemniej czyni to w celach o wiele szerszych niż obecny artykuł, skupiający się na problemie sytuowania Listów Pseudo-Dionizego w świetle wczesnej recepcji całości CD. 


\section{Corpus Dionysiacum: fałszerstwo czy fikcja literacka?}

Dziś, po długotrwałych i żmudnych poszukiwaniach tożsamości autora Corpus Dionysiacum, czy też: wedle starszej terminologii, Corpus Areopagiticum, jedna tylko kwestia nie ulega wątpliwości, a mianowicie fakt, że dzieło to napisał Pseudo-Dionizy, czy też Pseudo-Areopagita ${ }^{5}$, nie zaś Dionizy, znany ze świadectwa Dziejów Apostolskich ${ }^{6}$ lub z Historii Kościelnej Euzebiusza z Cezarei ${ }^{7}$. To ostatnie źródło, które łączy postać konwertyty Dionizego, słuchacza słynnej mowy św. Pawła na Areopagu z postacią Dionizego, pierwszego biskupa Aten, tworzy także inne ciekawe powiązanie. Oto bowiem informacji o identyczności obu ateńskich Dionizych zasięgnął Euzebiusz u innego jeszcze ich imiennika, Dionizego z Koryntu, który miał być nade wszystko płodnym epistolografem. Jak bowiem pisze historyk z Cezarei, wymieniając zasługi owego korynckiego biskupa: „[n]ajwiększy pożytek sprawił wszystkim swymi Listami katolickimi, które pisał do różnych Kościołów". Niewykluczone, że autor Corpus Dionysiacum, decydując się, by nadać części swych pism formę listu, liczył nie tylko na oczywiste dla chrześcijańskich czytelników skojarzenie z apostolską epistolografią, lecz także, że chciał on wywołać asocjacje z Dionizym korynckim i jego listami ${ }^{9}$. Niezależnie od trafności tego ostatniego przypuszczenia Pseudo-Dionizy Areopagita, jak się zrazu wydaje, podpada pod zawartą u Euzebiusza krytyczną ocenę Dionizego z Koryntu, który miał tak komentować fałszerstwa dokonywane na jego listach:

5 Gdyby prawdziwy autor korpusu miał na imię Dionizy, wówczas mielibyśmy do czynienia z Dionizym Pseudo-Areopagitą (jak w przypadku prób jego utożsamienia z Dionizym Wielkim, Małym czy Scholastykiem - por. zestawienie i problematyzacja także pozostałych prób identyfikacji autora Areopagityków w: R.F. Hathaway, Hierarchy and the Definition of Order in the Letters of Pseudo-Dionysius. A Study in the Form and Meaning of the Pseudo-Dionysian Writings, The Hague 1969, s. 31-35; M. Manikowski, Pierwsza Zasada, świat stworzony i drogi poznania. Pseudo-Dionizy Areopagita - jego filozofia i teologia, Kraków 2006, s. 32-61). W toku nowożytnej recepcji określenie Pseudo-Areopagita pojawia się w 1619 r. u Georga Calixta, określenie Pseudo-Dionizy związane jest natomiast $\mathrm{z}$ etapem współczesnej krytyki.

6 Dz 17, 34.

7 HE IV, 23.

8 Tamże, cyt. za: Euzebiusz z Cezarei, Historia Kościelna, oprac. H. Pietras, przekł. pol. A. Lisiecki, A. Caba, Kraków 2013, s. 275.

9 Podobne przypuszczenie wysuwa współcześnie Rosemary A. Arthur (w: Pseudo-Dionysius as Polemicist. The Development and Purpose of the Angelic Hierarchy in Sixth Century Syria, London 2008, s. 1); historycznie zaś - w kontekście wątpliwości związanych z paryską legendą Pseudo-Dionizego - taką możliwość rozpatrywał Piotr Abelard (por. P. Rorem, Pseudo-Dionysius. A Commentary on the Texts, dz. cyt., s. 16 wraz z odnośnikami). 
$\mathrm{Na}$ prośbę braci pisałem listy. Jednak apostołowie diabelscy domieszali do nich kąkol, tu coś wycinając, tu zaś dodając. Biada im! Nic dziwnego, że niektórzy z nich odważyli się fałszować nawet Pisma Pańskie, skoro dokonali takiego zamachu na inne pisma, niedorównujące tamtym ${ }^{10}$.

Pseudo-Dionizy Areopagita pozornie dokonał także swego rodzaju fałszerstwa, skoro podszył się pod autora z czasów apostolskich. Nie wydaje się jednak, by przywołanie ewangelicznej symboliki kąkolu w przytoczonym cytacie z Euzebiusza miało na celu krytykę podszywania się innych autorów pod Dionizego z Koryntu, co byłoby analogiczne do sytuacji Pseudo-Dionizego. Ów kąkol, co widać wyraźniej, gdy spojrzy się choćby na następny rozdział Historii kościelnej, poświęcony Teofilowi z Antiochii, oznacza po prostu herezję, a więc fałszowanie nauki apostolskiej pod względem treści ${ }^{11}$, a dopiero w dalszej kolejności, o ile w ogóle, ma on coś wspólnego z kwestią tożsamości autora.

Można założyć, biorąc pod uwagę choćby misterną konstrukcję całego Corpus Dionysiacum (zarówno jego części istniejących, jak i tych znanych tylko z na$\mathrm{zwy}^{12}$ ), że ich autor żyjący w V albo VI wieku ${ }^{13}$ nie tyle przekształcił istniejące utwory Dionizego z Aten dla własnych celów, co byłoby rodzajem fałszerstwa, opisanym przez Euzebiusza ${ }^{14}$, ile ustylizował dzieło własnego autorstwa na dawniejsze, by współczesnym jawiło się jako autorytatywnie prawdziwe. Jest to po części zgodne z dyrektywą zawartą w Liście VI Areopagityków: „powstrzymuj się od wszelkich oskarżeń wobec innych, a tylko rozprawiaj w taki sposób o prawdzie, aby to, co powiesz, stało się niepodważalne"15.

10 HE IV, 23; cyt. za: Euzebiusz z Cezarei, Historia Kościelna, dz. cyt., s. 279.

11 HE IV, 24.

12 Por. powyżej, przyp. 3.

13 Takie ostrożne sformułowanie pomija długotrwały spór pomiędzy datowaniem CD na 2. poł. w. V a 1 poł. w. VI, który rozpoczął się wraz z ukazaniem się pionierskich prac Hugona Kocha (z r. 1895) i Josepha Stiglmayra (z r. 1895 i zwłaszcza „drugiego przyczynka do pytania o Dionizego" z tego samego roku) i trwa do dziś - por. I. Perczel, Pseudo-Dionysius the Areopagite and the Pseudo-Dormition of the Holy Virgin, „Le Muséon” 2002, vol. 125, s. 56-60.

14 Dodatkową przesłanką, że nie mamy tu do czynienia z tego rodzaju fałszerstwem jest fakt, że nic nie wiemy o utworach owego opisanego w Dziejach Apostolskich Dionizego, który miał być także pierwszym biskupem Aten. Być może Pseudo-Dionizy też nic o nich nie wiedział, co mogło być jedną z zalet wyboru przez autora CD takiego pseudonimu.

15 Ep. VI, 1077A/B (164, 9-10); cyt. za: Pseudo-Dionizy Areopagita, Pisma teologiczne, przeł. M. Dzielska, przedm. T. Stępień, Kraków 2005, s. 339; por. Ep. VII, 1080A (165, 12-166, 6). 
Tak opisany zabieg uczynienia niepodważalnymi własnych słów niewątpliwie powiódł się Dionizemu, który dzięki pseudonimowi wzniósł się ponad bieżącą polemikę doktrynalną swoich czasów, do wątku tego jeszcze powrócę, i spełnił tym samym warunek powstrzymywania się od otwartych oskarżeń wobec innych. Co się jednak tyczy niepodważalności w znaczeniu samej prawdy przekazu, czyli prawowierności, która tylko formalnie stała się niepodważalna dla czytelników dzięki akceptacji apostolskiego autorytetu Areopagityków, stanowiła ona wielkie wyzwanie interpretacyjne.

\section{Zagadka wczesnej recepcji Pseudo-Dionizego}

Spisanie nowych utworów (nowych zarówno w sensie chronologii, jak i nowatorskiego sposobu stawiania kwestii, niewątpliwie inspirowanego późnym neoplatonizmem ${ }^{16}$ ) pod szatą starych oczywiście nie przesądzało z góry o ich ortodoksji, która to kwestia, jak już wspomniałam, przede wszystkim nurtowała choćby Dionizego z Koryntu, gdy uskarżał się na fałszerzy swoich listów.

Ponadto, ukrycie się rzeczywistego, historycznego Pseudo-Dionizego pod imieniem ucznia św. Pawła, które zwłaszcza należące do Corpus Dionysiacum listy - z racji ich przynależności gatunkowej - naraża na zarzut fikcyjności, nie zmienia faktu, że już w toku najwcześniejszej znanej nam recepcji jego utworów zarzut fałszerstwa został niemal jednogłośnie oddalony ${ }^{17}$. Co zaś ważniejsze z perspektywy nie tylko wczesnego, lecz także wielowiekowego późniejszego oddziaływania, Pseudo-Dionizy Areopagita od razu albo niemal od razu stał się

16 Zob. bardzo dobre i stosunkowo krótkie ujęcie tej kwestii wraz z literaturą przedmiotu w przywoływanym już tekście Wernera Beierwaltesa, Dionizy Areopagita - chrześcijański Proklos?. Do wątku tego jeszcze powrócę.

17 Często przywoływane wątpliwości Hypatiusza z Efezu co do autentyczności pism Dionizjańskich nie były w VI w. odosobnione, czego pośrednim świadectwem są chociażby Scholia Jana ze Scytopolis, ale też - jak można sądzić po szerokości pozytywnej recepcji (w tym i samego Jana) - nie należy przeceniać ich siły i znaczenia - por. P. Rorem, J.C. Lamoreaux, John of Scythopolis and the Dionysian Corpus. Annotating the Areopagite, Oxford 1998, s. 17-18. W późniejszym okresie, gdy Scholia Jana ze Scytopolis oraz Maksyma Wyznawcy niejako zrosły się z Areopagitykami, dowodem podobnego wahania jest dopiero wzmianka w Bibliotece Focjusza, kod. 1 [1a], skądinąd w kontekście obrony Corpus Dionysiacum przez niejakiego Teodora, żyjącego być może w VI w. (Focjusz, Biblioteka, t. 1: Kodeksy 1-150, przeł. O. Jurewicz, Warszawa 1986, s. 4, przyp. 2 i 3). Niestety ten rozdział polemiki w VI wieku nie jest nam bliżej znany (P. Rorem, J.C. Lamoreaux, John of Scythopolis..., dz. cyt., s. 105-106). 
Dionizym Areopagitą. Odkąd znalazł uznanie jako autor dawny, ale i ortodoksyjny, w czym wielki udział mieli Jan ze Scytopolis i Maksym Wyznawca, twórcy - nieodłącznych od Areopagityków - Scholiów, zaczęto nawet bronić jego dzieł, stosując zarzut fałszerstwa podobny do tego, który miał formułować Dionizy z Koryntu, a mianowicie, że niektóre fragmenty Corpus Dionysiacum modyfikowano w złej wierze. Tak zostały ocenione przez żyjącego w VIII wieku myśliciela Józefa Hazzaya niektóre fragmenty bardzo wczesnego syryjskiego (syriackiego) przekładu Sergiusza z Reszainy - rzecz charakterystyczna, przekład ów był wcześniejszy nawet niż najstarsze greckie Scholia, które w drugim tłumaczeniu syryjskim Fokasa bar Sergiusa włączono do tekstu ${ }^{18}$. Również za fałszerstwo uznano w toku toczących się w VII wieku sporów chrystologicznych wprowadzenie do treści Dionizjańskiego Listu IV drobnej, lecz znaczącej modyfikacji - zamiast o Chrystusowym „nowym bogoludzkim działaniu”, twórcy aleksandryjskiego porozumienia pomiędzy chalcedończykami (neochalcedończykami) a monofizytami (miafizytami) woleli mówić o ,jednym” takim działaniu. Biorąc pod uwagę możliwą, choć nigdzie niepotwierdzoną lekcję „wspólnym bogoludzkim

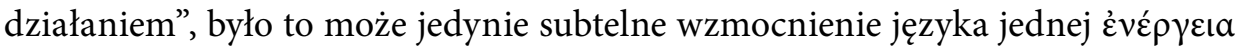

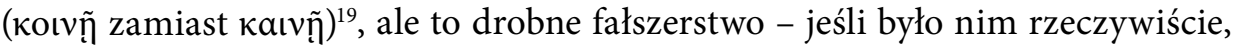
bo zachowały się głównie źródła chalcedońskie, dobitnie ukazuje, że w VII wieku pisma Pseudo-Dionizego cieszyły się już tak wielkim autorytetem, że opłacało się je modyfikować w celach doktrynalnej polemiki.

Dionizjański List IV w toku wczesnej greckiej recepcji Areopagityków jest jednak wyjątkowy - również w wieku VI był on przedmiotem dogmatycznej dys$\mathrm{kusji}^{20}$, czego nie można powiedzieć, przynajmniej biorąc pod uwagę stan naszej wiedzy, o większości pozostałych dzieł składających się na Corpus Dionysiacum (wykorzystywano jeszcze Imiona boskie, ale także w ograniczonym zakresie). Poza Scholiami nie podjęto wówczas w świecie greckim poświadczonej w źród-

18 Por. P. Rorem, J.C. Lamoreaux, John of Scythopolis..., dz. cyt., s. 107-108 oraz s. 37 i s. 105, przyp. 26; Ch.M. Stang, Apophasis and Pseudonymity in Dionysius the Areopagite: "No longer I", New York 2012, s. 23 i s. 24, przyp. 55; co może nieco zaskakujące, R.A. Arthur w: Pseudo-Dionysius as Polemicist..., dz. cyt. s. 138 i 186, wpisuje krytyczną reakcję Józefa w argumentację na rzecz Sergiuszowego autorstwa Corpus Dionysiacum.

19 Zob. moje Historyczne i doktrynalne uwarunkowania rozwoju myśli Maksyma Wyznawcy, Warszawa 2014, s. 123 i nn.); por. także nast. przyp.

20 Zob. streszczenie tych sporów w: P. Rorem, J.C. Lamoreaux, John of Scythopolis..., dz. cyt., s. 11-22; por. także dyskusję wokół domniemanych monofizyckich inklinacji Ps.-Dionizego w: M. Manikowski, Pierwsza Zasada..., dz. cyt., s. 34-35; 57-61 i 101-108. 
łach całościowej lektury Areopagityków, która, co więcej, nie byłaby uwikłana jedynie w spory chrystologiczne, do których Pseudo-Dionizy zdaje się odnosić $\mathrm{z}$ rezerwą. Areopagityki dostarczają bowiem jedynie bardzo skromnego materiału do technicznej dyskusji chrystologicznej (choć nawet te skrawki zostały skwapliwie wyzyskane przez uczestników sporów wokół liczby Chrystusowych natur, a w późniejszym czasie także wokół liczby działań i woli), ale nawet one są na tyle nieokreślone, że mogły być rzeczywiście interpretowane na korzyść nawet zwalczających się stronnictw owych sporów.

Być może przyczyną tej nieokreśloności był wpływ Henotikonu cesarza Zenona (jak sądził już Stiglmayr ${ }^{21}$ ), który zakazywał dyskusji nad liczbą natur Chrystusa. Innym możliwym wyjaśnieniem jest stylizacja Corpus Dionysiacum na czasy apostolskie (tak uważają Rorem i Lamoreaux ${ }^{22}$ ), w których wspomniane problemy liczby natur i im towarzyszące jeszcze nie zostały sformułowane, jednak należy wziąć pod uwagę także i inną przyczynę. Był to może skutek głębszego zamiaru Pseudo-Dionizego, by w ogóle nie podejmować technicznej dyskusji chrystologicznej. Z jednej strony wykraczała ona bowiem poza wspólną dla neoplatonizmu pogańskiego i chrześcijaństwa płaszczyznę dyskusji skupionej na filozofii Boga z jej odniesieniem do problematyki jedno - wiele, z drugiej zaś - w tym, co było krokiem Pseudo-Dionizego ku opisowi czysto już Chrystusowej teurgii nowego rodzaju, do wątku tego jeszcze powrócę, owa techniczna dyskusja przez jeszcze długi czas wprowadzała raczej zamęt, aniżeli konkretne dogmatyczne rozwiązania. Raz jeszcze przywołując fragment Listu VI, powstrzymywanie się od udziału w chrystologicznym sporze, było też właśnie powstrzymywaniem się „od wszelkich oskarżeń wobec innych” i zarazem sposobem na niepodważalność przekazu.

Jest więc kwestią godną przemyślenia, w jaki sposób „boski Dionizy”, tak pod względem zaangażowania doktrynalnego nieprzystający do swoich czasów, pojawił się na arenie dziejów, dając początek zarówno najwcześniejszej - paradoksalnie: chrystologicznej - recepcji, jak i późniejszym odczytaniom i nawiązaniom,

${ }_{21}$ Zob. tenże, Das Aufkommen der Pseudo-Dionysischen Schriften und ihr Eindringen in die christliche Literatur bis zum Lateranconcil 649, w: IV Jahresbericht des öffentlichen Privetgymnasiums an der Stella Matutina zu Feldkirche, Feldkirche 1895, s. 39 i nn.; w kontekście Dionizjańskich Listów por. także L. Couloubaritsis, Le statut de la critique dans les Lettres du Pseudo-Denys, „Byzantion” 1981, vol. 51, s. 112-121; wątpliwości co do tego związku wyrażali m.in. Rorem i Lamoreaux w: John of Scythopolis..., dz. cyt., s. 10 oraz István Perczel w artykule Pseudo-Dionysius the Areopagite and the Pseudo-Dormition..., dz. cyt., s. 58 i nn. 
lepiej oddającym specyfikę Dionizjańskiego dzieła, począwszy od wszechstronnego jego potraktowania w twórczości Maksyma Wyznawcy. Sądzę, że ogólna odpowiedź na tak postawione, również bardzo ogólne pytanie sprowadza się do bynajmniej nieoczywistej, jeśli chodzi o wnioski, konstatacji, że mnich Pseudo-Dionizy musiał pisać dla innych mnichów. Ci zaś wcale nie musieli pozostawić śladów swojej nawet bardzo powszechnej czy wnikliwej lektury. Dopiero w tym kontekście nabiera znaczenia interesujące spostrzeżenie Paula Rorema i Johna C. Lamoreaux, którzy z pewnym zdziwieniem odnotowali występowanie u Cyryla ze Scytopolis, autora „najbardziej niefilozoficznego z teologicznych pism w przebiegu VI stulecia”, źródłowo Dionizjańskiego terminu hierarchia ${ }^{23}$.

\section{Znaczenie kolejności dzieł w Corpus Dionysiacum}

Jest to, jeśli nie najważniejszy termin w całym Corpus Dionysiacum, to w każdym razie termin kluczowy dla obu Hierarchii - niebiańskiej i kościelnej, a także dla zbioru Listów. Tradycyjnie uznawano te właśnie dzieła za odpowiednio rozpoczynające i kończące całość Areopagityków, tzn. Hierarchie we wszystkich greckich manuskryptach otwierały korpus, podczas gdy Epistula go zamykały ${ }^{24}$. Stąd też nie można się zgodzić $\mathrm{z}$ twierdzeniem Rorema, że „[n]ie ma żadnej wskazówki, który z traktatów był właściwie napisany jako pierwszy, a stąd żadnej historycznie wiarygodnej wskazówki co do miejsca, w którym należy rozpocząć lekturę"25. Wprawdzie nie wiemy, które z pism zawartych w Corpus Dionysiacum powstało jako pierwsze, nie wiemy przecież nawet, ile tych pism rzeczywiście powstało, jeśli wziąć w rachubę zapowiedzi Pseudo-Dionizego ${ }^{26}$, ale zgodność rękopisów stanowi jednak przynajmniej właśnie historycznie wiarygodne świadectwo ich kolejności w toku już stosunkowo wczesnej recepcji (editio princeps Areopagityków wyszła od Jana ze Scytopolis). Nie unieważnia to oczywiście bardzo wartościowej próby komentatorskiej Rorema, który rozpoczyna swoje wprowadzenie do Pseudo-Dionizego od analizy Listów, co czyni z dwóch powodów - ich zaletami z pro-

23 P. Rorem, J.C. Lamoreaux, John of Scythopolis..., dz. cyt., s. 21, przyp. 41. W kwestii pochodzenia terminu zob. powyżej, przyp. 2.

24 Taką kolejność odnaleźć można także w dziele Patrologia Graeca Jacques’a Paula Migne’a; por. A. Golitzin, Mystagogy. A Monastic Reading of Dionysius Areopagita, s. xxxvi.

25 Pseudo-Dionysius. A Commentary..., s. 6.

26 Por. powyżej, przyp. 3. 
pedeutycznego punktu widzenia są, w jego ujęciu, ich krótkość oraz zawartość niemal wszystkich zagadnień, poruszanych w innych znanych utworach, a nawet w dziełach jedynie sygnalizowanych tytułem (przykładowo w Liście IX do Tytusa mamy pełne streszczenie nieznanej nam, a być może w ogóle niepowstałej Teologii symbolicznej $\left.{ }^{27}\right)$. Jednakże lektura Listów jako jedynie wprowadzenia do traktatów nie oddaje im sprawiedliwości, jeśli rzeczywiście są to pisma końcowe i jeśli całość Corpus Dionysiacum należy odczytywać wedle klucza mystagogicznego, co zwłaszcza w świetle wywodów Teologii mistycznej - skądinąd często postrzeganych jako ostatnie słowo Dionizjańskiego korpusu - wydaje się trafne.

Problemem jest zatem nie to, czy mystagogiczna lektura Areopagityków ma w ogóle rację bytu, ale czy wtajemniczenie proponowane czytelnikom przez Pseudo-Dionizego osiąga swoje zwieńczenie w Teologii mistycznej czy w Listach. Biorąc już pod uwagę sam tekst, łatwo zauważyć, że zakończenie Teologii i początek Epistula są ściśle powiązane motywem jasności i ciemności poznania, a sama dynamika wznoszenia załamuje się na Liście II, gdy z wyżyn boskiej niewiedzy czytelnik powraca do rozważania Boga w Bóstwie i Dobru, co stanowi już poziom intelektualnego rozważania, charakterystyczny dla - wcześniejszych niż ostatni - rozdziałów Teologii mistycznej oraz dla Imion boskich ${ }^{28}$. Zstępowanie rozpoczyna się natomiast w Liście III z jego słynnym początkowym „nagle”, literalnie współbrzmiącym zresztą i to zapewne zamierzenie z Platońskim غ̇ંaí $\varphi v \varepsilon \varsigma^{29}$. Tę drogę zstępującą można już otwarcie traktować jako chrystocentryczną, jest ona bowiem odejściem od porządku ściśle hierarchicznego, całkowicie niespodziewaną i udzieloną darmo osobistą ingerencją Boga $\mathrm{w}$ dzieje $\mathrm{e}^{30}$. Zstępowanie dotyczy wszak samej boskiej nadsubstancjalności, która „przyjmuje ludzką

27 O której mowa również w III rozdz. MTh.

28 Por. podsumowanie DN w MTh III.

29 Zbieżność Dionizjańskiego Ep. III z Platońskim użyciem tego terminu, a w szczególności $\mathrm{z}$ brzmieniem trzeciej hipotezy z Parmenidesa, była szeroko omawiana w literaturze przedmiotu - zob. np. W. Beierwaltes, 'E $\xi \alpha i \varphi v \varepsilon \varsigma$ oder die Paradoxie des Augenblicks, „Philosophisches Jahrbuch" 1966/67, vol. 74, s. 271-283; tenże, Dionizy Areopagita - chrześcijański Proklos?, dz. cyt., s. 71-76; w kluczu chrystocentrycznym zob. A. Golitzin, Mystagogy..., dz. cyt., s. 41 i nn. oraz tenże, Revisiting the 'Sudden': Epistle III in the Corpus Dionysiacum, „Studia Patristica” 2001, vol. 37, s. 482-491. Zbieżność ta stała się nawet źródłem interesującej, choć odmawiającej Pseudo-Dionizemu tożsamości chrześcijańskiej, całościowej lektury Listów w monografii R.F. Hathawaya, Hierarchy and the Definition...; por. także I. Perczel, The Christology of Pseudo-Dionysius the Areopagite: The Fourth Letter in Its Indirect and Direct Traditions, „Le Muséon” 2004, vol. 117, s. 409-412.

Por. jednak w tym chrystocentrycznym kontekście również DN I, 4 (od 592A; 113, 6). 
substancjalność”31 i poprzez „nowe bogoludzkie działanie” - to już wzmiankowany wcześniej List IV - odsłania opisaną w Liście $V$ świetlistą ciemność, która nie jest ani czystą katafazą teologii pozytywnej, ani czystą apofazą teologii negatywnej, lecz samoudzielaniem się Logosu w objawieniu. Dalsze Epistula w różnoraki sposób opisują to bogoludzkie udzielanie się - zarówno jego aspekt poznawczy (odrzucenie, by użyć określenia Lambrosa Couloubartsisa, refutatywnej dialektyki w Liście VI i Liście VII², znaki opisane w Liście VII i sposoby wysłowienia Pisma, analizowane w Liście IX), jak i dobroczynny (dobrodziejstwa hierarchicznego porządku, do których jeszcze powrócę, wskazywane w Liście VIII, dobrodziejstwa bezpośredniej soteriologicznej Bożej ingerencji, ukazane poprzez opowiadanie snu Karposa z Listu VIII oraz eschatologicznie pobrzmiewająca zapowiedź uwolnienia Jana z Listu X).

\section{Misterna konstrukcja Listów: fikcyjność i celowość}

Chrystocentryczne odczytywanie Epistula nie wyklucza jednak lektury skoncentrowanej na wspomnianym już pojęciu hierarchii. Oto bowiem, adresatami Listów są kolejno przedstawiciele: stanu mniszego ${ }^{33}$ (Gajusz - Listy od I do IV), diakonatu (Doroteusz - List V), stanu kapłańskiego (Sozipater - List VI), biskupstwa (Polikarp - List VII i Tytus - List IX) oraz - w kontekście hierarchii pojętej jako tradycja Kościoła - stanu apostolskiego (Jan Ewangelista w Liście X) ${ }^{34}$. Badacze często zwracają uwagę na zachwianie tego układu, jakim jest adresowanie Listu VIII do mnicha Demofila. List ten poświęcony jest jednak w swej większej części właśnie problematyce zachwiania hierarchii przez Demofila, mnicha bezprawnie upominającego kapłana, co w wystarczający sposób wyjaśnia wyrazisty zabieg Pseudo-Dionizego ${ }^{35}$.

Przegląd adresatów Dionizjańskiej epistolografii dobrze ukazuje również spójność tego podzbioru Corpus Dionysiacum, którą uwyraźnia także tematyczne zazębianie się poszczególnych Listów, podobne do tego, z jakim mieliśmy do

\footnotetext{
31 Ep. III, 1069B (159, 6); cyt. za: Pseudo-Dionizy Areopagita, Pisma teologiczne, s. 336.

32 L. Couloubaritsis, Le statut..., s. 112-121.

33 W braku laikatu ma on zapewne reprezentować całość chrześcijańskiej wspólnoty.

34 Polikarp i Tytus również wpisują się w tę apostolską linię, w którą wpisują się przecież wszyscy biskupi.

35 Por. P. Rorem, Pseudo-Dionysius. A Commentary..., s. 18-24; T. Stępień, Hierarchia..., s. 166-168.
} 
czynienia pomiędzy Teologią mistyczną a całością Epistula. Misterna konstrukcja epistolograficznej części Areopagityków jest jednak zarazem dowodem, że są to listy fikcyjne - co więcej, także traktaty mają przecież swoich adresatów i nie wyróżnia ich spodziewana odmienna długość ${ }^{36}$. Wybór listownej formy - właściwie jedynie czysto nominalnej, szczególnie w przypadku pierwszych pięciu listów - wydaje się podyktowany zamysłem stylizowania utworów na czasy apostolskie, co uwidaczniają bogate w Listach elementy uprawdopodabniające ich dawność: poza imionami Gajusza, Tytusa, Polikarpa i Jana, relacja Pseudo-Dionizego z jego rzekomego świadkowania ciemnościom zalegającym ziemię w dniu śmierci Jezusa i odwołanie do wczesnochrześcijańskiej opowieści w relacji ze snu Karposa. Logika ukrywania się pod pseudonimem nie zakłada jednak, by autor Areopagityków zamierzał przede wszystkim stworzyć u czytelników wrażenie, że mają oni do czynienia $\mathrm{z}$ autentycznymi listami - listy poruszają bowiem zagadnienia bardzo uniwersalne. Lektura tak dawnej epistolografii (pomiędzy rzekomą datą powstania Corpus Dionysiacum a datą jego faktycznego powstania rozciąga się okres co najmniej czterech stuleci) zawsze poniekąd abstrahuje od jej zawartości faktograficznej. Fakty opisane w dawnych listach zawsze czyta się przecież z myślą o współczesności. Zgodnie z interesującą hipotezą bpa Alexandra Golitzina bezpośrednim kontekstem powstania Listów i całego korpusu pism była polemika $\mathrm{z}$ wciąż istniejącym w VI wieku w Syrii, prawdopodobnej ojczyźnie Pseudo-Dionizego, nurtem mesalianizującym, który podkopywał wiarę w potrzebę kościelnego i sakramentalnego pośrednictwa w drodze do Boga ${ }^{37}$. Dalsze rozpowszechnienie się Areopagityków w gronach monastycznych, w tym sukces dzieła przypieczętowany Dionizjańską recepcją w dziele Maksyma Wyznawcy i w czasach późniejszych, miały już odmienne konteksty - wykorzystanie Listu IV w dziedzinie chrystologii jest tylko pierwszym znanym greckim polem, na którym uznany apostolski autorytet Corpus Dionysiacum okazał się pomocny.

Jeśli natomiast forma listowna części Areopagityków miała do odegrania szczególną rolę na tle traktatów należących do dzieła Dionizjańskiego, było nią, poza utwierdzeniem datowania zgodnego z pseudonimem autora, nadanie rozważaniom bardziej partykularnego charakteru. Podczas gdy jednak autentyczne listy z czasów apostolskich i wczesnochrześcijańskich były faktycznie odpowiedziami na konkretne problemy Kościołów i jednostek, lecz ostały się jako uni-

36 Por. A. Louth, Denys the Areopagite, dz. cyt., s. 17.

37 A. Golitzin, Mystagogy..., dz. cyt., s. xxxiii-xxxvii. 
wersalne fragmenty Pisma czy Tradycji, to Listy Dionizjańskie, choć w swojej fikcyjności i archaizacji miały już charakter literackiego uogólnienia, zachęcały do spojrzenia na całość Areopagityków w perspektywie jednorazowości wcielenia i jednorazowości dziejów pojedynczego chrześcijanina oraz jego hierarchicznej wspólnoty.

\section{Zakończenie}

Wymieniając części składowe Corpus Dionysiacum, łatwo skupić się na Imionach boskich oraz Teologii mistycznej, a także na Hierarchiach niebiańskiej i kościelnej, a następnie dopiero po chwili namysłu dodać: „A, i jeszcze Listy” 38 . Wydaje mi się, że taka niefrasobliwość w traktowaniu epistolograficznej części dzieła Pseudo-Dionizego może skutkować zachwianiem - i tak już częściowo zachwianych przez samego autora - proporcji pomiędzy uprawianymi przez niego rodzajami teologii. Skupienie się zaś na hierarchicznym porządku Hierarchii kościelnej i niebiańskiej, teologii naturalnej Imion boskich czy apofatyce Teologii mistycznej, choć każde z tych dzieł zawiera elementy oryginalnie chrześcijańskie, także te płynące $z$ objawienia, jak w przypadku biblijnych imion Boga, czynić może $\mathrm{z}$ „boskiego Dionizego" po prostu jednego z neoplatoników - chrześcijańskiego Proklosa czy chrześcijańskiego Damaskiosa. Dzięki poważniejszemu potraktowaniu Listów z ich subtelnym, ale wyraźnym otwarciem na misterium wcielenia, Pseudo-Dionizy może się jawić bardziej jako twórca nowej filozofii, symbolicznie powtarzając sytuację i przesłanie mowy św. Pawła na Areopagu. W tym sensie pseudonim Dionizy, choć w bezwzględnych miarach antydatowany, $\mathrm{z}$ teologicznego i historiozoficznego punktu widzenia wydaje się adekwatny. Listy są, jak sądzę, tą częścią Corpus Dionysiacum, która najlepiej uwiarygodnia tę względną miarę.

38 Można podać wiele przykładów takiego pominięcia, ograniczę się jedynie do dwóch: W. Beierwaltes, Dionizy Areopagita - chrześcijański Proklos?, dz. cyt., s. 39 (wprawdzie autor wspomina o „kilku listach”, o których zresztą pisze w dalszych częściach wywodu, to jednak po raz pierwszy charakteryzując układ CD, nie wymienia Epistula ani z nazwy, ani nie włącza ich do wstępnie zarysowanego planu całości Areopagityków); Piotr Sikora natomiast, choć słusznie zaznacza, że zarówno w średniowieczu, jak i później najczęściej komentowane były DN i MTh ze szkodą dla głębszej recepcji $\mathrm{CH}$ i EH, nie wspomina w tym kontekście o Listach (zob. tenże, Logos niepojęty. Teza „Jezus jako petnia objawienia” w perspektywie teologii apofatycznej. Analiza filozoficzna, Kraków 2010, s. 58-59). 


\section{Bibliografia}

\section{Źródła}

Corpus Dionysiacum I. Pseudo-Dionysius Areopagita: De divinis nominibus, B.M. Suchla (ed.), Walter de Gruyter, Berlin-New York 1990.

Corpus Dionysiacum II. Pseudo-Dionysius Areopagita: De coelesti hierarchia. De ecclesiastica hierarchia. De mystica theologia. Epistulae, G. Heil, A. M. Ritter (eds.), Walter de Gruyter, Berlin-New York 1991.

Pseudo-Dionizy Areopagita, Pisma teologiczne, przeł. M. Dzielska, przedm. T. Stępień, Znak, Kraków 2005.

Euzebiusz z Cezarei, Historia Kościelna, oprac. H. Pietras, przekł. pol. A. Lisiecki, A. Caba, Wydawnictwo WAM, Kraków 2013.

Focjusz, Biblioteka, t. 1: Kodeksy 1-150, przeł. O. Jurewicz, Instytut Wydawniczy PAX, Warszawa 1986.

\section{Opracowania}

Arthur R.A., Pseudo-Dionysius as Polemicist. The Development and Purpose of the Angelic Hierarchy in Sixth Century Syria, Ashgate, London 2008.

Balthasar von, H.U., Chwała. Estetyka teologiczna, t. 2, cz. 1, przeł. E. Marszał i J. Zakrzewski, Wydawnictwo WAM, Kraków 2007.

Beierwaltes W., Dionizy Areopagita - chrześcijański Proklos?, w: tenże, Platonizm $w$ chrześcijaństwie, przeł. P. Domański, Wydawnictwo ANTYK, Kęty 2003, s. 38-76.

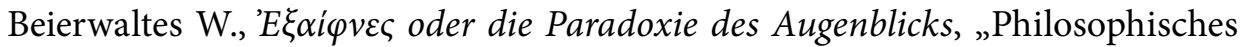
Jahrbuch" 1966/67, vol. 74, s. 271-283.

Carabine D., The Unknown God. Negative Theology in the Platonic Tradition: Plato to Eriugena, Peeters, Louvain 1995.

Couloubaritsis L., Le statut de la critique dans les Lettres du Pseudo-Denys, „Byzantion" 1981, vol. 51, s. 112-121.

Golitzin A., Revisiting the 'Sudden': Epistle III in the Corpus Dionysiacum, „Studia Patristica” 2001, vol. 37, s. 482-491.

Golitzin A., Et introibo ad altare Dei: Mystagogy of Dionysius Areopagita, George

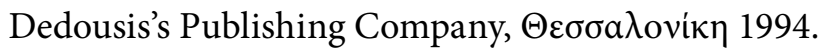


Golitzin A., Mystagogy. A Monastic Reading of Dionysius Areopagita, Cistercian Publications, Collegeville, Minnesota 2013.

Golitzin A., Revisiting the 'Sudden': Epistle III in the Corpus Dionysiacum, „Studia Patristica” 2001, vol. 37, s. 482-491.

Hathaway R.F., Hierarchy and the Definition of Order in the Letters of Pseudo-Dionysius. A Study in the Form and Meaning of the Pseudo-Dionysian Writings, Springer, The Hague 1969.

Koch H., Proklos als Quelle des Pseudo-Dionysius Areopagita in der Lehre von Bösen, „Philologus“ 54 (1895), s. 438-454.

Kosmulska B., Historyczne i doktrynalne uwarunkowania rozwoju myśli Maksyma Wyznawcy, Campidoglio, Warszawa 2014.

Louth A., Denys the Areopagite, Continuum, London-New York 1989.

Manikowski M., Pierwsza Zasada, świat stworzony i drogi poznania. Pseudo-Dionizy Areopagita - jego filozofia i teologia, Aureus, Kraków 2006.

Meyendorff J., Teologia bizantyjska. Historia i doktryna, przeł. J. Prokopiuk, WUJ, Kraków 2007.

Perczel I., Pseudo-Dionysius the Areopagite and the Pseudo-Dormition of the Holy Virgin, „Le Muséon” 2002, vol. 125, s. 55-97.

Perczel I., The Christology of Pseudo-Dionysius the Areopagite: The Fourth Letter in Its Indirect and Direct Traditions, „Le Museon” 2004, vol. 117, s. 409-446.

Rorem P., Pseudo-Dionysius. A Commentary on the Texts and Introduction to Their Influence, Oxford University Press, New York - Oxford 1993.

Rorem P., Lamoreaux J.C., John of Scythopolis and the Dionysian Corpus. Annotating the Areopagite, Clarendon Press, Oxford 1998.

Stang Ch.M., Apophasis and Pseudonymity in Dionysius the Areopagite: "No longer I", Oxford University Press, New York 2012.

Sikora P., Logos niepojęty. Teza „Jezus jako petnia objawienia” w perspektywie teologii apofatycznej. Analiza filozoficzna, rozdz. III, Universitas, Kraków 2010.

Stępień T., Hierarchia niebiańska jako wzór idealnej społeczności. Polityczny aspekt myśli Pseudo-Dionizego Areopagity, „Warszawskie Studia Teologiczne” 2014, t. 27, z. 1, s. 161-170.

Stiglmayr J., Das Aufkommen der Pseudo-Dionysischen Schriften und ihr Eindringen in die christliche Literatur bis zum Lateranconcil 649, zamieszczoną w „Jahresbericht des öffentlichen Privetgymnasiums an der Stella Matutina zu Feldkirch“ 4 (1895), s. 3-96. 
Stiglmayr J., Der Neuplatoniker Proklos als Vorlage des sog. Dionysius Areopagita in der Lehre vom Übel, „Historisches Jahrbuch“ 16 (1895), s. 253-273, 721-748. Świtkiewicz-Blandzi A., Pseudo-Dionizy a Grzegorz Palamas. Bizantyjska synte$z a$ wschodniej patrystyki, Wydawnictwo Naukowe Sub Lupa, Warszawa 2018. Tichy R., Ukryte Oblicze. O mistyce i mesjanizmie, Flos Carmeli, Poznań 2013.

\section{Streszczenie}

Artykuł ma celu przedstawić kilka kwestii dotyczących tak samego tajemniczego autora Corpus Dionysiacum, jak i jego odczytywania w większej mierze w świetle Dionizjańskich Listów oraz ich wczesnej recepcji (VI-VII w.).

Słowa kluczowe: Pseudo-Dionizy Areopagita, Corpus Dionysiacum, hierarchia, lektura mystagogiczna

\section{Summary}

\section{The Place and Role of the Letters in Pseudo-Dionysian Writings}

The article aims to present some questions concerning the mysterious author of Corpus Dionysiacum as well as of its lecture more in the light of Dionysian Letters and their early reception (6th -7 th c.).

Key words: Pseudo-Dionysius the Areopagite, Corpus Dionysiacum, hierarchy, mystagogical lecture 